\title{
SLC5A8 wt Allele
}

National Cancer Institute

\section{Source}

National Cancer Institute. SLC5A8 wt Allele. NCI Thesaurus. Code C121498.

Human SLC5A8 wild-type allele is located in the vicinity of $12 \mathrm{q} 23.1$ and is approximately $55 \mathrm{~kb}$ in length. This allele, which encodes sodium-coupled monocarboxylate transporter 1 protein, plays a role in iodide transport and the sodium ion-dependent transport of monocarboxylates. 